\title{
Serological studies of West Nile virus in a liver transplant population
}

\author{
LE Nicolle MD FRCPC ${ }^{1,2}$, A Gutkin ${ }^{1}$, G Smart BSc (Hon) $\mathrm{RT}^{3}, \mathrm{M}$ Dawood PhD ${ }^{2,3}, \mathrm{M}$ Drebot PhD ${ }^{2,4}$, \\ P Van Caeseele MD FRCPC ${ }^{2,3}$, A Giulivi MD FRCPC ${ }^{5}$, GY Minuk MD FRCPC ${ }^{1}$
}

\begin{abstract}
LE Nicolle, A Gutkin, G Smart, et al. Serological studies of West Nile virus in a liver transplant population. Can J Infect Dis Med Microbiol 2004;15(5):271-274.
\end{abstract}

BACKGROUND: Solid organ transplant populations are at increased risk for serious clinical manifestations of West Nile virus (WNV) infection.

OBJECTIVE: To monitor liver transplant recipients during the 2003 WNV season in Manitoba and to identify incidence, clinical presentation and serology.

METHODS: Serial blood specimens were obtained from adult patients followed at the liver transplant outpatient clinic between May 2003 and October 2003. Studies for WNV infection included immunoglobulin (Ig) $\mathrm{G}$ and IgM enzyme immunoassay (EIA), hemagglutination inhibition (HI), plaque reduction neutralization test and reverse transcriptase-polymerase chain reaction.

RESULTS: None of the 79 patients had clinical presentations suggestive of WNV infection. On testing of the final serum specimen obtained, 14 patients (18\%) had positive IgG anti-WNV by EIA and six patients (7\%) had indeterminate IgG anti-WNV by EIA, although all were negative by IgM EIA. Four (20\%) of the EIA-positive samples were reactive by $\mathrm{HI}$, but all of these were negative by WNV plaque reduction neutralization test; this is consistent with the presence of non-West Nile flavivirus antibody in these sera. Blood specimens obtained throughout the season from EIA- and HI-positive individuals were uniformly negative for WNV-RNA by reverse transcriptasepolymerase chain reaction. Age, sex, hematology and biochemistry findings, hepatitis $\mathrm{B}$ or $\mathrm{C}$ virus status, immunosuppressive regimen (cyclosporin or tacrolimus) and pretransplant diagnosis of liver disease were similar for EIA-positive and EIA-negative patients. For the 10 patients with a positive IgG EIA maintained on cyclosporin, the cyclosporin level was $129.1 \pm 28.6 \mu \mathrm{g} / \mathrm{L}$ compared with $85.6 \pm 36.7 \mu \mathrm{g} / \mathrm{L}$ in 26 patients who were EIA-negative $(\mathrm{P}=0.002)$.

CONCLUSIONS: False-positive IgG EIA serology for WNV was common in this cohort of liver transplant recipients, and was associated with elevated serum cyclosporin levels.

\section{Des études sérologiques du virus du Nil occidental dans une population de greffés hépatiques}

HISTORIQUE : La population de greffés d'un organe solide est plus vulnérable aux manifestations cliniques graves de l'infection au virus du Nil occidental (VNO).

OBJECTIF : Évaluer les greffés du foie pendant la saison 2003 du VNO au Manitoba et repérer l'incidence, la présentation clinique et la sérologie.

MÉTHODOLOGIE : Des spécimens sanguins sériques ont été obtenus auprès de patients adultes suivis à la clinique ambulatoire des greffés du foie entre mai et octobre 2003. Les études de l'infection au VNO incluaient le dosage immunoenzymatique (DIE) de l'immunoglobuline (Ig) $\mathrm{G}$ et de l'IgM, l'inhibition de l'hémagglutination (IH), le test de séroneutralisation par réduction des plaques et la méthode PCR-CDNA. RÉSULTATS : Aucun des 79 patients n'avait de présentations cliniques laissant supposer la présence d'un VNO. Pour ce qui est du spécimen sérique final obtenu, 14 patients (18\%) avaient un IgG anti-VNO positif par DIE, et six (7\%), un IgG anti-VNO indéterminé par DIE, même si tous étaient négatifs par DIE de l'IgM. Quatre (20\%) des échantillons positifs au DIE étaient réactifs à l'IH, mais tous étaient négatifs selon le test de séroneutralisation par réduction des plaques. Ces observations étaient cohérentes avec la présence d'anticorps à flavivirus ne provenant pas du VNO dans ces sérums. Les spécimens de sang obtenus pendant la saison auprès d'individus positifs selon le DIE et l'IH étaient tous négatifs à l'ARN du VNO selon la méthode PCR-CDNA. L'âge, le sexe, les observations hématologiques et biochimiques, l'état du virus de l'hépatite $\mathrm{B}$ ou C, la posologie immunosuppressive (cyclosporine ou tacrolimus) et le diagnostic de maladie hépatique avant la transplantation étaient similaires chez les patients positifs ou négatifs selon le DIE. Pour les 10 patients traités à la cyclosporine ayant un IgG positif par DIE, le taux de cyclosporine était de $129,1 \pm 28,6 \mu \mathrm{g} / \mathrm{mL}$ par rapport à $85,6 \pm 36,7 \mu \mathrm{g} / \mathrm{mL}$ chez 26 patients négatifs selon le DIE $(\mathrm{P}=0,002)$.

CONCLUSIONS : Une sérologie fausse positive du DIE de l'IgG pour le VNO était courante dans cette cohorte de greffés du foie et s'associait à des taux de cyclosporine sérique élevés.

Key Words: Liver transplant; Manitoba; West Nile virus

$T^{h}$ he West Nile virus (WNV) is a flavivirus classified in the Japanese encephalitis antigenic complex (1). It was introduced into North America via New York City, USA, in 1999 (2). The virus has subsequently progressed across North America, causing morbidity and mortality in humans and wild and domestic animals $(1,3)$. The majority of human infections are asymptomatic, but serious clinical presentations such as meningoencephalitis can occur and are associated with significant morbidity and occasional mortality (1). The North American experience with this virus has identified

Departments of ${ }^{1}$ Internal Medicine and ${ }^{2}$ Medical Microbiology, University of Manitoba; ${ }^{3}$ Cadham Provincial Laboratory; ${ }^{4}$ National Microbiology Laboratory, Winnipeg, Manitoba; ${ }^{5}$ Centre for Infectious Diseases Control, Ottawa, Ontario

Correspondence: Dr LE Nicolle, Departments of Internal Medicine and Medical Microbiology, University of Manitoba, Health Sciences Centre, Room GG443, 820 Sherbrook Street, Winnipeg, Manitoba R3A 1R9. Telephone 204-787-7029, fax 204-787-4826,

e-mail lnicolle@hsc.mb.ca

Received and accepted for publication September 14, 2004. 


\begin{tabular}{|c|c|}
\hline Mean age \pm SD (range) & $53 \pm 16$ years (range $20-80$ ) \\
\hline Female subjects, $\mathrm{n}(\%)$ & $45(57)$ \\
\hline \multicolumn{2}{|l|}{ Hematology (mean \pm SD [range]) } \\
\hline Hemoglobin, $g / L(n=72)$ & $127 \pm 17(92-173)$ \\
\hline Leukocyte count, $\times 10^{9} / L(n=72)$ & $6.3 \pm 2.8(1.8-23)$ \\
\hline INR $(n=71)$ & $1.1 \pm 0.2(0.9-2.3)$ \\
\hline \multicolumn{2}{|c|}{ Serum biochemistry (mean \pm SD [range]) } \\
\hline $\mathrm{ALT}, \mathrm{U} / \mathrm{L}(\mathrm{n}=77)$ & $47 \pm 45(7-319)$ \\
\hline AST, U/L ( $n=70)$ & $43 \pm 37(12-257)$ \\
\hline Alkaline phosphatase, $\mathrm{U} / \mathrm{L}(\mathrm{n}=72)$ & $154 \pm 138(45-951)$ \\
\hline $\begin{array}{l}\text { Gamma-glutamyltransferase, } \\
\qquad / L(n=72)\end{array}$ & $149 \pm 287(6.5-2258)$ \\
\hline Albumin, $g / L(n=72)$ & $37 \pm 4.0(20-47)$ \\
\hline Bilirubin, $\mu \mathrm{mol} / \mathrm{L}(\mathrm{n}=71)$ & $13 \pm 8.5(3-46)$ \\
\hline Creatinine, $\mu \mathrm{mol} / \mathrm{L}(\mathrm{n}=72)$ & $119 \pm 76(48-656)$ \\
\hline \multicolumn{2}{|l|}{ Hepatitis serology, n (\%) } \\
\hline HCV-positive & $9(11)$ \\
\hline HBV-positive & $2(2.5)$ \\
\hline \multicolumn{2}{|l|}{$\begin{array}{l}\text { Immunosuppressive levels } \\
\text { (mean } \pm \mathrm{SD} \text { [range]) }\end{array}$} \\
\hline Cyclosporin A, $\mu \mathrm{g} / \mathrm{L}(\mathrm{n}=41)$ & $103 \pm 41(25-181)$ \\
\hline Tacrolimus, $\mu \mathrm{g} / \mathrm{L}(\mathrm{n}=25)$ & $7.4 \pm 2.1(4.2-13)$ \\
\hline
\end{tabular}

ALT Alanine aminotransferase; AST Aspartate aminotransferase; HBV Hepatitis B virus; $\mathrm{HCV}$ Hepatitis $C$ virus; INR International normalized ratio

immunocompromised patients, including solid organ transplant recipients, as a group with increased risk for more severe manifestations of the illness (4-7). During summer 2003, it was anticipated that human cases of WNV would occur for the first time in Manitoba. The present study, which enrolled a cohort of adult liver transplant patients in Winnipeg, Manitoba, focused on identifying cases of the disease and characterizing laboratory and clinical observations. While no cases of WNV infection were identified in this cohort, a high prevalence of false-positive serum immunoglobulin (Ig) G enzyme immunoassay (EIA) was observed.

\section{Study population}

\section{METHODS}

Adult patients who had undergone orthoptic or living related liver transplantation and were subsequently followed by the liver transplant evaluation and follow-up clinic at the Health Sciences Centre (Winnipeg, Manitoba) provided verbal consent for serological testing and monitoring of clinical status from May 2003 to October 2003. A total of 79 individuals, representing approximately $80 \%$ of the total transplant recipient population, agreed to participate.

\section{Study design and data collection}

This study was designed to be a prospective observational cohort study. Clinical monitoring was performed by telephone contact every two weeks between May 15, 2003 and October 31, 2003. A standardized checklist at each interview identified symptoms potentially consistent with WNV infection and explored mosquito exposure. At regularly scheduled transplant follow-up visits (usually every four to six weeks), routine blood work - including biochemistry, complete blood count and cyclosporin A or tacrolimus levels was obtained for transplantation follow-up. Testing for WNV was performed on aliquots of these sera. Serum specimens were forwarded to the Cadham Provincial Laboratory (Winnipeg, Manitoba) and stored at $-70^{\circ} \mathrm{C}$ until testing was performed. The initial specimen from each patient was collected in May, and the final specimens were collected in September or October.

\section{Laboratory studies}

For patients without clinical findings potentially consistent with WNV infection, WNV IgG EIA and IgM EIA $(8,9)$ were measured on the final serum specimen collected in the fall. Positive samples by EIA (greater than 0.9 ) were further tested by hemagglutination inhibition (HI) and plaque reduction neutralization test (PRNT). A fourfold increase in WNV antibodies, an EIA greater than 0.9 or a single titre of one in 320 or greater by $\mathrm{HI}$ testing was considered suggestive of WNV infection. Sera positive for both EIA and HI were further tested by real-time reverse transcriptase-polymerase chain reaction (RT-PCR) for WNV-RNA. The Cadham Provincial Laboratory (CPL) then performed EIA (IgG and IgM) using WNV ELISA IgG and WNV IgM capture ELISA (Focus Technologies Inc, USA) and RT-PCR (Artus Biotech, USA). HI testing was also performed at the CPL using antigen provided by the National Microbiology Laboratory (NML) (Winnipeg, Manitoba) (8). PRNTs were carried out by the NML $(8,9)$. Trough cyclosporin levels were determined on whole blood following protein precipitation using monoclonal-based fluorescence polarization (Cyclosporin Monoclonal Whole Blood Reagent Pack, Abbott Laboratories, USA).

\section{Patient population and exposures}

Characteristics of the 79 patients enrolled in the study are shown in Table 1. Pretransplant liver disease was attributable to primary biliary cirrhosis in 15 subjects, fulminant hepatic failure in nine subjects, hepatitis $\mathrm{C}$ infection in eight subjects, primary sclerosing cholangitis in seven subjects, autoimmune hepatitis in seven subjects, cryptogenic cirrhosis in six subjects and alcohol-induced liver disease in five subjects. There were three patients each with alpha-1-antitrypsin deficiency, hepatocellular carcinoma and Wilson's disease. Finally, there were 13 patients with other reasons for transplantation. Three of 20 subjects $(15 \%)$ tested had positive rheumatoid factor, 19 of 70 subjects $(27 \%)$ had positive antinuclear antibody, three of 70 subjects $(4.3 \%)$ had antismooth muscle antibody and 16 of 70 subjects (23\%) had antimitochondrial antibody. Sixty-six of 79 patients received either cyclosporin or tacrolimus; the remaining 13 received mycophenolate mofetil, sirolimus, prednisone or a combination of these drugs.

During summer 2003, 142 human cases of WNV were identified in Manitoba, with earliest onset in July and latest onset at the end of September. None of the patients in the cohort presented with clinical signs or symptoms suggestive of WNV infection. The frequency of self-reported mosquito bites ranged from zero to less than four per day. Only two subjects reported a mean of greater than four mosquito bites per day.

\section{WNV serology}

Of the 79 subjects tested for WNV by EIA, 14 (18\%) were positive (WNV-IgG greater than 1.1) and six (7\%) were indeterminate (greater than 0.9 but less than 1.1) (Table 2). None of 
these 20 samples were WNV-IgM EIA-positive, but four (20\%) were reactive to WNV by HI. Three of these four samples had low HI titres: two had a titre of 1:10, one had a titre of $1: 20$ and one individual had a titre of 1:160. The four HI reactive cases for WNV were also positive for St Louis Encephalitis, and the individual with the highest WNV titre also had positive HI results for Powassan virus and dengue. This is consistent with the cross-reactivity of the HI assay for flavivirus antibody. All patients with WNV-IgG EIA positive assays and negative results on $\mathrm{HI}$ testing were negative for these other viruses. One individual had a western equine encephalitis titre of 1:20. By PRNT assay, all four of the HI-reactive samples were negative for WNV, although two were positive for dengue. Serial serum samples collected throughout the summer season from the four patients reactive by HI testing were analyzed for WNV-RNA by real-time RT-PCR. The results of 13 specimens tested (five, four, three and one from the four patients) were uniformly negative. Thus, all positive serum samples were interpreted as false-positives rather than consistent with recent or remote WNV infection.

\section{Analysis of false positives}

Patients with positive IgG EIA for WNV were compared with patients who were serologically negative. There were no differences in age, sex, hematology, biochemistry, presence of antinuclear antibodies, antismooth muscle antibodies, antimitochondrial antibodies or hepatitis $\mathrm{B}$ or $\mathrm{C}$ virus serology. Three of 20 subjects (15\%) positive for WNV-IgG were also rheumatoid factor-positive. Of the 10 EIA-positive patients receiving cyclosporin, the mean trough cyclosporin level in specimens collected over the period of observation was $129.1 \pm 28.6 \mu \mathrm{g} / \mathrm{L}$, compared with $85.6 \pm 36.8 \mu \mathrm{g} / \mathrm{L}$ for the 26 patients receiving cyclosporin with negative IgG-EIA $(\mathrm{P}=0.002)$. There was no correlation between individual cyclosporin A levels and WNV-IgG levels (data not shown). In addition, direct assay with cyclosporin added to negative control sera showed no cross-reactivity of cyclosporin in the EIA.

The two patients with positive PRNT results for dengue had both been born and initially lived in dengue endemic areas: a patient from Trinidad who had left 38 years previously, and a patient from the Philippines who had left 28 years previously. Three other patients - two HI-reactive patients and one western equine encephalitis-positive patient - had resided in Manitoba or southern Saskatchewan throughout their lives.

\section{CONCLUSIONS}

The present study identified no acute WNV infections in a cohort of liver transplant recipients during the first year of WNV human disease in this area of Canada. However, a high false-positive rate of $25 \%$ was observed with WNV-IgG EIA testing. High false-positive rates in serology for Japanese encephalitis group viruses are well recognized $(9,10)$, and are attributable to cross-reactivity due to shared antigens among viruses in the group, as well as nonspecific reactions due to autoantibodies such as rheumatoid factor. In our patients, prior infections with cross-reacting viruses (particularly dengue) may have contributed. While autoantibodies were common in this population with significant liver disease, they were not more common among patients with false-positive reactions. The only significant difference observed in a comparison
TABLE 2

Results of serological and nucleic acid testing for West Nile virus (WNV)

\begin{tabular}{ll}
\hline & Number (\%) \\
\hline WNV immunoglobulin IgG EIA & $20(25)$ \\
Positive $(>1.1)$ & $14(18)$ (range 1.1-3.5) \\
Indeterminate $(>0.9,<1.1)$ & $6(7)$ \\
Additional testing on IgG EIA-positive & \\
WNV IgM EIA & $0 / 20$ \\
WNV - HI-positive: (\%) & $4 / 20(20)$ \\
St Louis Encephalitis & 4 \\
Powassan virus & 1 \\
Dengue & 1 \\
PRNT of HI-positive & 0 \\
WNV & $2 / 4$ \\
Dengue & 0 \\
WNV-RNA of HI-positive &
\end{tabular}

EIA Enzyme immunoassay; HI Hemagglutination inhibition; IgG Immunoglobulin G; PRNT Plaque reduction neutralization test

between those with negative serology and those with positive serology was the mean cyclosporin level for those maintained on cyclosporin. The explanation for this observation is not clear.

The high rate of IgG false positivity is not a concern for the misdiagnosis of acute infection because the IgM test was uniformly negative. However, in North America (an area with no previous incidence of human WNV cases), the 25\% falsepositive rate seems exceptionally high. In New York City, a serosurvey performed in the fall after the initial outbreak in 1999 found an infection prevalence of 2.6\% (11). In 2000, a serosurvey in Connecticut (following a large epizootic in 1999) found no individuals with positive serology (12). In contrast, the prevalence of antibodies in Israel - where WNV has been endemic - increased from $7 \%$ in 18 - to 20 -year-old soldiers to $42 \%$ in those 40 to 55 years of age (13). These observations are likely partially explained by prior exposures to other flaviviruses such as dengue. A potential alternate explanation (which requires further evaluation) is whether observations are characteristic of the commercial test used, because high false-positive rates have been observed in other serosurveys using this test (M Drebot, personal communication). The HI results are consistent with this notion. The observation of a relationship between cyclosporin level and positive $\operatorname{IgG}$ antibodies is of interest, and raises the possibility that cyclosporin or its metabolites may lead to immunomodulatory effects, which increase the likelihood of false-positive EIA reactions. Importantly, an association between autoantibodies and the presence of false-positive serology was not observed, although the numbers were small.

ACKNOWLEDGEMENT: We thank Maya Andonova for technical assistance and Brenda Des Rosiers for secretarial support.

\section{REFERENCES}

1. Petersen LR, Marfin AA. West Nile virus: A primer for the clinician. Ann Intern Med 2002;137:173-9.

2. Nash D, Mostashari F, Fine A, et al. The outbreak of West Nile virus infection in the New York City area in 1999. N Engl J Med 2001;344:1807-14.

3. Pepperell C, Rau N, Krajden S, et al. West Nile virus infection in 2002: Morbidity and mortality among patients admitted to hospital in southcentral Ontario. CMAJ 2003;168:1399-405. 
4. Iwamoto M, Jernigan DB, Guasch A, et al. Transmission of West Nile virus from an organ donor to four transplant recipients. N Eng J Med 2003;348:2196-203.

5. Cushing MM, Brat DJ, Mosunjae MI, et al. Fatal West Nile virus encephalitis in a renal transplant recipient. Am J Clin Pathol 2004;121:26-31.

6. Kumar D, Prasad GV, Zaltzman J, Levy GA, Humar A. Communityacquired West Nile virus infection in solid-organ transplant recipients. Transplantation 2004;77:399-402.

7. Ravindra KV, Freifeld AG, Kalil AC, et al. West Nile virusassociated encephalitis on recipients of renal and pancreas transplants: Case series and literature review. Clin Infect Dis 2004:38:1257-60

8. Calisher CH, Karabatsos N, Dalrymple JM, et al. Antigenic relationships between flaviviruses as determined by crossneutralization tests with polyclonal antisera. J Gen Virol 1989;70:37-43.
9. Drebot MA, Lindsay R, Barker IK, et al. West Nile virus surveillance and diagnostics: A Canadian perspective.

Can J Infect Dis 2003;14:105-14.

10. Shi PY, Wong SJ. Serologic diagnosis of West Nile virus infection. Expert Rev Mol Diagn 2003;3:733-41.

11. Mostashari F, Bunning ML, Kitsutani PT, et al. Epidemic West Nile encephalitis, New York, 1999: Results of a household-based seroepidemiological survey. Lancet 2001;358:261-4.

12. Handler J, Nelson R, McCarthy T, et al. West Nile virus surveillance in Connecticut in 2000: An intense epizootic without high risk for severe human disease. Emerg Infect Dis 2001;7:636-42.

13. Cohen R, Ksiazek TG, Shemer J, Green MS. Prevalence of antibodies to West Nile fever, sandfly fever Sicilian and sandfly fever Naples viruses in healthy adults in Israel. Public Health Rev 1999;27:217-30. 


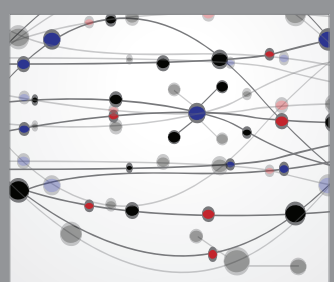

The Scientific World Journal
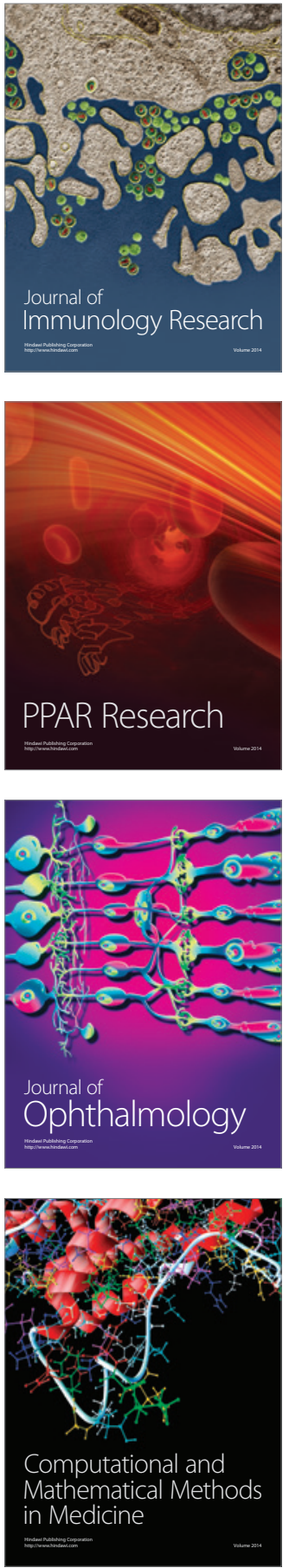

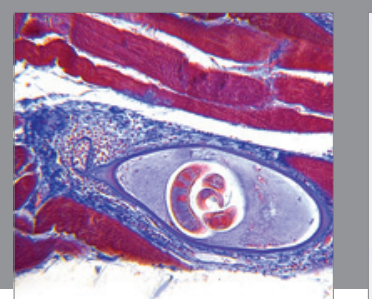

Gastroenterology Research and Practice

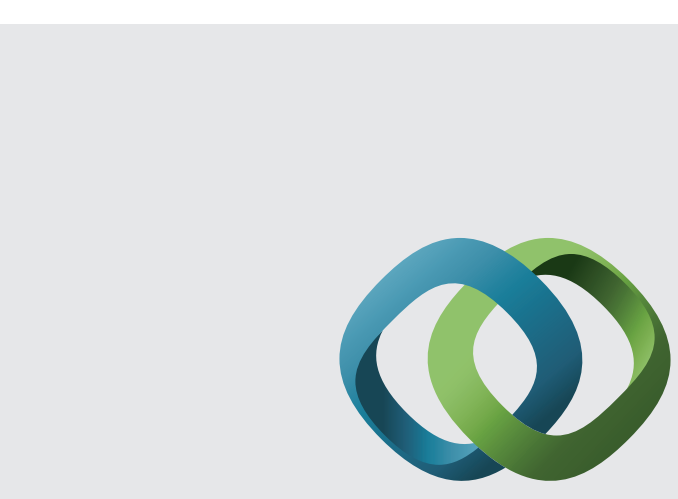

\section{Hindawi}

Submit your manuscripts at

http://www.hindawi.com
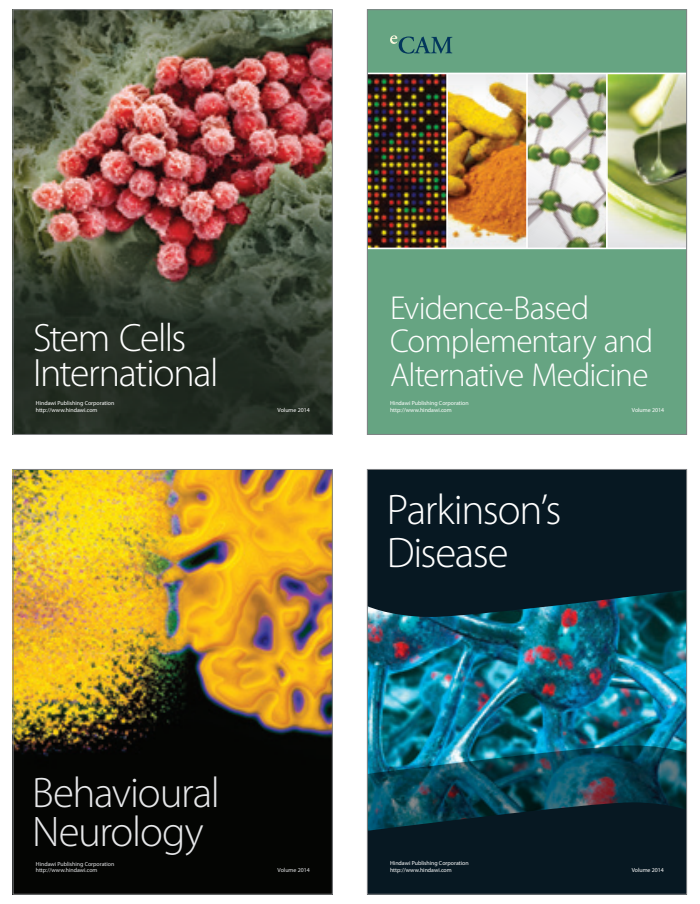
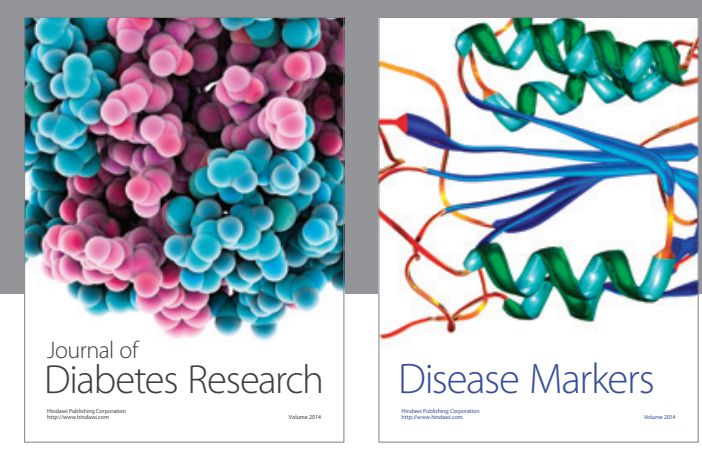

Disease Markers
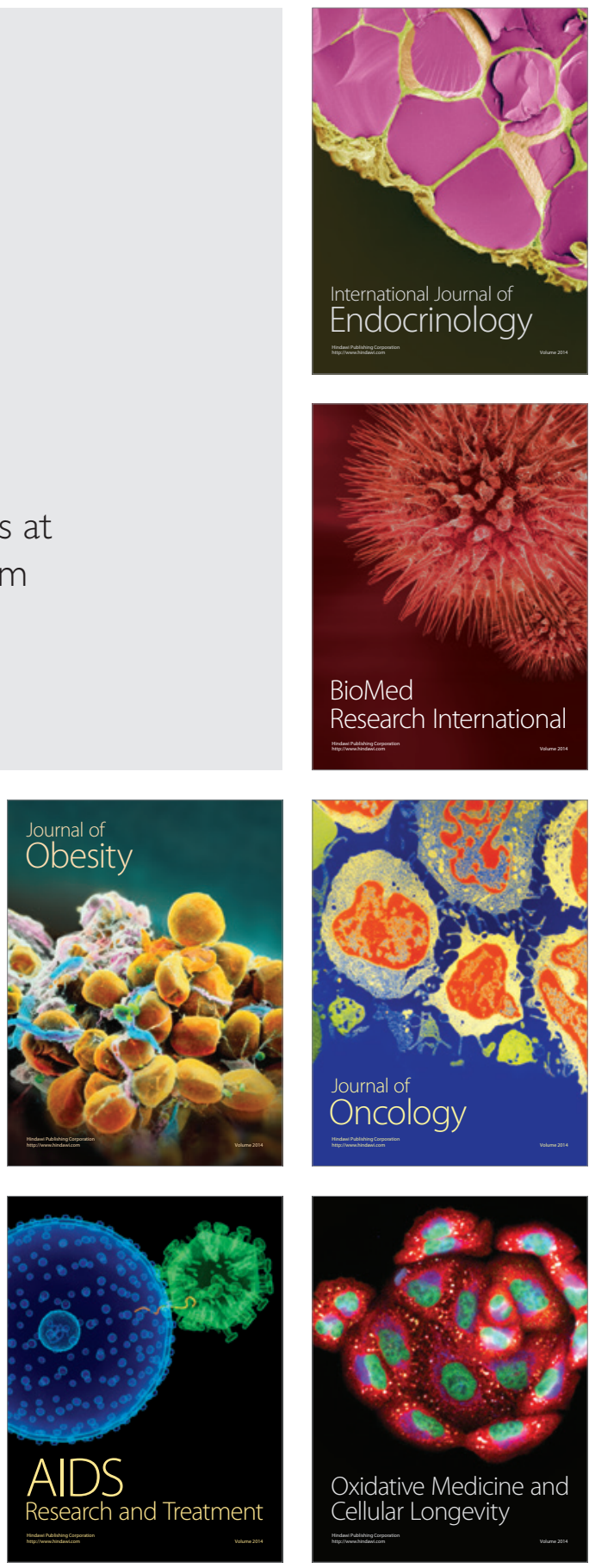